\title{
Low and High Potentials of Entrepreneurial Development within the Framework of Indigenious Small Scale Management in Africa
}

\author{
Olatunji Eniola Sule ${ }^{1}$ \\ ${ }^{1}$ Business and Finance Department, Crescent University, Abeokuta, Nigeria \\ Correspondence: Olatunji Eniola Sule (MNIM), Business and Finance Department, Crescent University, Km 5, \\ Ayetoro Road, Lafenwa, P.M.B. 2104, Sapon, Abeokuta, Ogun State, Nigeria. Tel: 234-80-6342-8299, \\ 234-80-5603-7734. E-mail: olasem2005@yahoo.com
}

Received: November 9, 2012

Accepted: February 14, $2013 \quad$ Online Published: May 12, 2013

doi:10.5430/ijba.v4n3p41

URL: http://dx.doi.org/10.5430/ijba.v4n3p41

\begin{abstract}
This work looked at the potentials of entrepreneurship development within the framework of indigenous small scale management. It also show those potentials that are inherent in entrepreneurs of small scale business both low and high potentials and possibly expose some of the problems or drawbacks of entrepreneur of small scale business in Africa. The writer try to show what small scale business is like and possibly other scholars' assumptions of what small scale business is all about. Finally, some suggestions were proffered by the writer based on the personal experiences on how to enhance the potentials of entrepreneurs of small scale business in Nigeria and possibly, the entire continent of Africa; talking about how to cope with, both internal and external environmental forces of the business.
\end{abstract}

Keywords: enterprise, small scale business, business potentials, indigenous entrepreneur

\section{Introduction}

An entrepreneur is that person who is in effective control of commercial understanding or rather, a person who undertakes a business or enterprise, with chances of profit or loss. But we have been made to understand by many scholars that entrepreneur could be a group of persons who make decisions for the business. However, Professor Peter Drucker in the Practice of Management said that "if we want to know what a business is, we have to start with its purpose. There is only one valid definition of business purpose - "to create a customer."

Business, therefore, is "the sum total of those activities that have as their main purpose the creation, maintenance and extension of a concern which continues to exist because it earns profits or other benefits or money". (Wayne McNaughton). A business, therefore, could be international or indigenous depending on the scope of operation of such enterprise. A business is said to be international according to Jaja and Okwandu, (2000) "when there is institutional arrangements and practices that facilitate the exchange of commodities, services, technology, and managerial ideas across national frontiers." While it is indigenous if it is within the national frontier, such business does not operate beyond the shore of their country. They do not have any dealing whatsoever with other organisation and/or person beyond their country.

However, it is usually, the wish of every entrepreneur to make the business international but most businesses remain indigenous due to many factors like limited resources, government policies, lack of international opportunities and so on. Furthermore, while a business remain indigenous it can be small or large scale business. It is large scale business where the ownership and the management of such business is not vested in the same person; also where the Chief Executive does not participate in most level of decision making and he does not know all the employees of such organisation and vice versa. Small scale business have small number of employees not above one hundred; ownership and management rest with one single person; such organisation cannot influence the price of the product in the industrial sector which such business belongs and many more.

Again, entrepreneur is defined by Jaja (2000) as "individuals and groups that possess the ability to visualize and assess latent business opportunities. It extends to their effort in setting mission and targets; assembles the necessary resources so as to reap the advantages accruing from business opportunities." Nevertheless, entrepreneur in small 
scale business tends to be innovative in the line of business they get involved in; they also have great potential for growth as well as having strategic objectives.

This work is, therefore, going to look at the potentials of entrepreneurial development within the framework of indigenous small scale management. In other words, the write-up will try to show those potentials that are inherent in entrepreneurs of small scale business both low and high potentials and possibly expose some of the problems or drawbacks of entrepreneur of small scale business in Africa.

But for a better understanding, there is need to try to 'paint a picture' of what a small scale business is like to the author in particular and the general assumption. Finally, some suggestions will be proffer by the writer based on the personal experience on how to enhance the potentials of entrepreneurs of small scale business in Nigeria and possibly, the entire continent of Africa. That is, ways of coping with environmental forces (both internal and external) of the business.

\section{Characteristics of Small Scale Business}

Small scale business mean different thing to different people, and whatever description giving to small scale business tends to suit it. This tends to be a problem as to which business is to be categorised as small scale business and which one is large scale business. But the two main yardsticks for classifying a business as small scale are size and government policy. They can again be spitted into the size of the employees, size of market shares, size of the profit, size of capital employed and government policy on the number of employees in the organisation, government policy on the business market shares, government policy on the profit margin and government policy on the capital employed.

The size of employees differs based on different schools of thoughts. While some say the organisation with about fifty employees or below; others say it is one hundred employees or below and other group is of the opinion that it must be two hundred employees. But I feel the bone of contention have to do with the fact that the size of the employees of such organisation should be very insignificant.

The sales volume and the business market share is another yardstick for classification. It is the belief of some that the sales volume in Naira of small scale business must not be more than Two Hundred and Fifty Thousand Naira while some say it is allowed to the tune of Five Hundred Thousand Naira but another group says it is one million naira below that qualified a business as small scale business. But this have to do with the trend of the economy in such country at a particular point in time as well as the inflation rate at the time in question.

Consideration was also made of the level of profitability of such business. Is it a business that declares profit frequently and if yes, what is the size or volume of such profit. Strictly, the level of profit has to do with the level of investment of any business. In as much as it is not that if you invest so much, you must definitely reap higher profit; as well you cannot invest as little as One Hundred Thousand Naira and expect profit of over Ten Million Naira in a fiscal year, except in a highly extreme cases.

Capital employed, though have several meanings as the term is often used quite loosely. At an elementary level, it is taken to mean the effective amount of money that is being used in the business. Thus, if all the assets were added together and the liabilities of the business deducted the answer would be the amount of money employed in the business.

But for the purpose of this write-up, capital employed will be the entrepreneur stake in the business. The size of such capital employed is another yardstick to determine whether or not a business is small or large scale. While some say below Five Hundred Thousand Naira is sufficient to qualify a business as small scale, others say it is Two Hundred and Fifty Thousand Naira below, while some are of the opinion that it is One Million Naira below.

Considering government policy on number of employees an organisation gainfully employed; the proportion of market share an organisation must possess; the profit margin or rather the level of profitability such organization makes annually and the capital employed. All these put together, the government of the day fix the minimum and maximum level for small and large scale. Most times, the issue is politicized, such that it does not have a meaningful correlation with the actual happenings in the society at such period.

Certain characteristics use, then, to determine which business is small or large scale. First, is the ownership and management of such enterprise. Where the owner of the enterprise is the sole manger saddled with the entire management responsibilities, then such business is said to be small compared with a situation where you cannot even identify who the actual owner is. This is because such owner(s) does not get involved in day-to-day running of the business. A very good example is enterprises with many shareholders; they meet once in a year to saddle few 
selected persons to manage the enterprise. Even where the shareholder/owner enters the premise of such enterprise, nobody recognize such persons as a part-owner of the enterprise. This is what we refer to as large scale enterprise. Another characteristic is the market size or rather market share. This is the size or the proportion of the total market cum-customers the enterprise has been able to "capture" as a real and potential customer. Therefore, if the enterprise is able to control a large share of the market then it can conveniently influence the happening in such market like the price of the product. But a situation where the enterprise is not the market leader nor market challenger but just a market follower; such enterprise will be seen as a small scale business. This is due to the fact that it cannot dictate the pace of anything in the market. Others set the pace for such enterprise to follow.

The next characteristics of a business is the fact that Chief Executive-workers interrelationships. This is talking about the entire work force knowing who their Chief Executive is physically and possibly have personal interaction with such Chief Executive. This can only occur in small scale business; in large scale business the workers may just be hearing the name of such Chief Executive only and may not be opportuned to interact with such Chief Executive. Also, a situation where the Chief Executive knows the entire (or most of the) work force is still pointing to the fact that the business is small scale business. In large scale business like UAC or African Petroleum in Nigeria; it is not easy for the Chief Executive to know ten percent of the work force even if they come into the establishment through him. But in most small scale business almost all the workers take instruction from Chief Executive on daily basis, as such they know him and what are his character, skill, intelligence and so on and can conveniently predict such Chief Executive at any point in time. But it cannot be the same in large scale business enterprise.

Furthermore, in small scale enterprise, the chief Executive generally participate in most level of decision making without adequate specialist squad. When you talk of recruitment, the Chief Executive is involved; accounting and other specialist work, the Chief Executive is always involved. But in large scale enterprise, you have specialist manager taking care of different area and aspect of the job. For instance, you have human resources, finance, marketing, sales, production managers and so on. Each and every one looks after a separate function and possibly reporting to the Chief Executive directly or indirectly depending on how the organogram directs.

On the final note, the classification of an enterprise can be seen from the true perception of the owner or the entrepreneur. This is because you know yourself better than any other individual. If your business is large, you should be able to tell yourself the truth and where it is small you need not deceive yourself as it is the case of Enron Company of United States of America that was as dead as a corpse and the Chief Executive was busy deceiving the entire world in collaboration with the company's auditor (Arthur Anderson).

However, the most general factor for categorizing a business whether large or small include the nature of business ownership. Nature of business ownership relates to how ownership is; is it a sole trade or joint venture. What is the liability stand of the owners? Like in a sole trader, the liability of the owner is unlimited while in public limited liability enterprise, the liability of the owners is limited to their commitment in the business. In a limited liability by shares, the volume of capital the enterprise will be able to generate will be higher and bigger than that of sole trade or partnership business as such the scope of operation will be wider enough to make the enterprise a large scale even if it was not large before.

Management and control of operation of an enterprise is another categorizing factor of a business. Mary Parker Follett defined management as "getting things done through other people". This is only carried out properly in large scale enterprise not in small scale. Management and ownership of enterprise mostly lies on the shoulder of one and same person in the case of small scale enterprises but there is always specialist taking care of different specialization in large scale enterprises. It is more of collective reasoning in terms of control of operation in large scale enterprise.

Again, the enterprise employees' population is another factor use in categorizing a business. This is talking about how many individuals are being recruited to carry out one responsibility or the other by an enterprise. The larger the employees' number in a particular enterprise dictates which category such an enterprise belongs to. For instance, compare an enterprise with a total of two thousand five hundred (2500) workers on its payroll with an enterprise with twenty to thirty workers. Without being told, one definitely knows that the enterprise with two thousand five hundred (2500) workers is a large scale enterprise while that with twenty workers is a small scale enterprise.

Value of capital employed by enterprise as earlier mentioned is another determining factor to classify a business as small or large scale. Small scale businesses employed mostly little or no capital. This is due to the size of ownership and consequently resources. Where more people put little resources together it makes a big resource. Little drop of water makes an ocean is the wise saying. Though the term capital employed had earlier been explained, it must be noted that the volume of capital employed determine the level of certain things done in an enterprise; like the kind of operation, control, number of employees employed, production capacity, and sales volume. 
Another factor for categorizing a business is the sales volume. Sales volume is predetermined by the marketing activities (market research) carried out by the enterprise. Most small scale enterprise find market research as too expensive to embark on, and as such their sales volume is restricted to only where they are aware of. You can only see only where you know while visualizing is the wise saying. But where there is adequate and proper market research, new and potential customers will be identified; there will be innovation due to new ideas generated; new area of needs for the enterprise products will be identified and many more; which will consequently improve and increase the sales volume. Therefore, large sales volume is synonymous with large scale enterprise.

We, also, have interpersonal relationship among the chief executive and the workers. This is the way workers relate with their chief executive. The chief executives of small scale enterprises know all their workers and have more and better interpersonal relationship among them. But in most large scale enterprises most of the workers will not know in person who their chief executive is and how do you relate with the person you did not know.

Finally, the nature of the industry is talking about which class of industry the enterprise belongs. Is it manufacturing, banking, hotel, and many more? Which of this industry did such enterprise belong to, if it is manufacturing industries, for instance, there is high tendency that the enterprise will be a large scale as most of the manufacturing industries are high capital intensive unlike hotel industry, for instance, which can be started on a low scale.

\section{Potentials of Small Scale Management}

Small scale business enjoys a lot of potentials over and above the large scale business which could be, as well, be grouped into low and high potentials. By low potentials, we are talking in terms of short term capability of coming into being or action while high potentials are long-run/term potentials that accrued to small scale business, overtime.

Innovation is said to be an important potential of small scale business in Africa. Most entrepreneurs want to come up with something new and different from what is obtainable in and around their business. This could be in form of alteration to existing product or making changes. Whichever way it comes, it has to be something new, one way or the other. MacDonald's Corporation, the great maker of take-away snacks is more relevant in this area. The entrepreneur started then, with the idea of producing a fast food system for passers-by to buy and eat on their way home or to offices in their car or bus.

It was a new idea in such environment then just as that of UAC Plc (Mr. Biggs) was an innovation in Nigeria. Since everyone realizes that it is only change that is constant; we tend to adjust or rather move with time consciously or unconsciously. Still on the example mentioned, Mr. Biggs was said to be for the bachelors and spinsters but with time we found out that number of married couples that visit Mr. Biggs has out-passed that of the 'single' men and women. Most of them visit even with their children but the issue is that we recognized a change brought about by entrepreneur and want to adapt and adopt it. Consequently, the entrepreneur enjoys better patronage and eventually becomes a successful Chief executive and in most cases the businesses becomes bigger and even grows to a large scale industry or enterprise. Still on the McDonalds Corporation which is known worldwide today; it started like a "child play" by Dick and Mac in 1937 who were brothers before Ray Kroc in 1957 help expand McDonald based on his sales practice which was based on analyzing the customers operations and suggesting changes to enhance them and in the process increase his sales.

Another potential of small scale business management is the potential for growth. Small scale business possess a large potential for growth due to many factors, some of which include the personal involvement of the owner in the management of the business; the thinking and reasoning that the doom of such business dictate the direction of the personal life of the owner, the zeal to succeed and become great by the owner and/or the entrepreneur. Just like we have seen in the case of MacDonald's, most small scale enterprises enjoy more patronage and due to the innovativeness the tendency to growth are always high. Because as everybody want to be identified with new things the entrepreneur is busy thinking of how to make the customer make what is called repeat purchase. Repeat purchase necessitates the entrepreneur to improve on many things to attract the customer.

Apart from all these growth which comes as a result of the Chief executive interpersonal relationship with the workers. Such Chief executive in most cases is able to identify areas of problems both on the job and that of the workers. Prompt attention are given to such identified problems which makes the product to improve, that is, workers are motivated and made to be more committed which reflect on the workers output and as such give room for adequate growth of such enterprise. It is said that to whom much is give much is expected. If much is given to the workers and enterprises generally, in terms of attention and others, then much growth is expected. This will not be the same in large scale enterprise where the chief executive does not know half of the workforce and information as 
to workers well being are communicated to chief executive through the functional officers and such information will be filtered, distorted, reduced the sensitivity, overloaded or even block the essential facts in the message.

The small scale enterprises also have much potential for growth due to the government policy on promoting self-sufficiency. In this case everybody is encouraged to go into self employment programme and a lot of facilities are put in place for the small scale enterprise to survive. Where small scale businesses are successful it saves the government the problem of dwindling the foreign exchange reserves. This is because the country will export more than it will be importing and make way for a favourable balance of payment of the country. Also, plan for economic development is directed at the attainment of self-sufficiency in production of economic goods and it is the small scale business that are more in such business, hence, their growth is inevitable.

Finally, small scale enterprises have the potential for strategic objective. Most small scale enterprises are established for certain specific purposes apart from profit maximization. Like in the case of MacDonald, it was first established to cater for car hop drive-in, that is, just stop for a while not necessarily parking to buy a fast food. This is due to the ability of the entrepreneur to be innovative and in innovation; something new is invented to solve a particular and peculiar problem not just producing. Also, most small scale enterprise comes up as a result of personal experience(s) of the entrepreneur about certain things; going into business with the thinking and idea on how to solve that particular problem also might make the enterprise objective very strategic in nature and implementation.

It must be noted that targets could be set which will be achievable but the strategy to achieve such target is the most important. Two different entrepreneurs can be in the same business but with different 'destination'. Most large scale enterprises go into operation basically for a particular and common objective and goal of profit and wealth maximization. But in small scale business because of the zeal to grow and succeed, the objective needs to be more strategic. The insufficient of fund can even be working against being strategic in objective by small scale enterprises. Just to do the right thing at the right time and at once; no room for "try and error" syndrome as found in large scale enterprises mostly.

\section{Small Scale Business Management Drawbacks}

For a business with high potentials, one may be deceived to think and even conclude that all ought to be well with such business. It must be noted that for anything that have advantage, there must be disadvantage.

One of the drawbacks of small scale business is the inability of the entrepreneur to procure skill manpower which result in poor and weak management. We have discussed earlier the small scale business not having adequate specialist squad. This could be due to financial incapability or that the stage of growth of the enterprise at that period does not give room for hiring of specialist. Work or rather responsibilities that should have been handled and carried out accurately and timely too are usually left in the hands of unskilled workers to try and see how best they can do it or at times all responsibilities left on the 'shoulder' of the entrepreneur who is likely to be the same owner. This also might be due to biasness based on personal judgment and reasoning. For instance, there is an oil servicing company based in Port Harcourt, Nigeria, that is being headed by a school certificate holder in the name - General Manager. This is due to the personal 'biasness' of the owner of the enterprise that the man in question has long being working for him. The final end result of such set-up is poor and unskilled management of the enterprise; since there is going to be different kind of conflicts facing such enterprise.

Another drawback of small scale business is the lack of adequate government encouragement and research as well as economic and political problem. Though, it is being reiterated all the time, by government, to encourage small scale business, the implementation of such policy has always face administrative bottleneck or even where it is implemented it will be poorly implemented. Small scale business contribute so much to the national development in terms of employment creation, economic activities and being a training instrument for the populace but still encouragement from the proper government quarter is not forthcoming and where it is given it is very, very insignificant.

Though, in taxing personal income, exception is given to the amount used for research as a way to encourage further research and development but what will always come out of the result of such research. Dr. Agbalaka's case, a medical expert in Nigeria is a very good example. Government was soliciting for a cure for HIV disease but refused to reckon with claim to have discovered a permanent cure for the disease by Doctor Agbalaka. This is very synonymous with African countries and this affect the growth of small scale business. Very many does not want to carry out research and where it is carried out it is done poorly with little or nothing to contribute to the existing body of knowledge. 
Political and economic problem is another drawback created by our government. We always have unstable economic climate and very unpredictable political situation; change in power today means change in everything about and from the government, nothing like continuity. Let us have a retrace of Nigeria situation from General Olusegun Obasanjo regime to President Olusegun Obasanjo regime. We have 'Operation Feed the Nation (OFN)' by General Obasanjo which I presumed metamorphosed into 'Obasanjo Farms Nigeria Limited' owned and directed by Olusegun Obasanjo as a private entity, now. This is followed by President Shehu Aliu Usman Shagari 'Austerity Measure'. General Mohammed Buhari cum Tunde Idiagbon came with War Against Indiscipline followed by 'Structural Adjustment Programme' (SAP) by General and President Ibrahim Badamosi Babaginda. Late General Sani Abacha came with 'War Against Indiscipline and Corruption' (WAIC) and today our President, Chief Olusegun Obasanjo is talking about 'Poverty Alleviation Programme'. No continuity! All, to me is for selfish and/or political gain. All these changes in economic policies and political situation affect the growth and continuous existence of small scale business.

Problem of time utilization due to advance technology is another important drawback affecting small scale business in Africa. Time management is as important as other resources; it is said that time wait for no one; time again is said to be money and once lost it cannot be regained. But in small scale business, time utilization becomes a problem as a result of technological advancement. Things that are supposed to be done within a twinkle of eye, takes hours or even days to be done. For instance, most small scale businesses still use the known Olympia typewriter to type documents. But with the computer you can type, make correction, print and keep a file within a short time and call back the same file as and when necessary.

The syndrome of follow-your-leader is another drawback of small scale business in Africa. Creating new idea by small scale business is always a problem as the entrepreneurs are always scared since they cannot dictate the pace in the industry. In marketing, they refer to such class of business as market follower while some are market leader, market challenger and nicher. Large scale enterprises dictate the "tone" of everything in such industry while most small scale enterprises follow. But there is always room for challenge even if you cannot lead; challenging the leader means making an attempt to cerate something new but very similar to what the market leader is presently doing. It makes the market more competitive, innovative and very interesting. In some cases, market challenger can become the leader if what is used in challenging the leader is well accepted, but you start a million kilometers journey with a step forward and this involve a lot of risk which many small scale entrepreneur always try as much as possible to avoid.

Finally, sluggishness in decision making is another drawback of small scale business. Small scale entrepreneurs are very sluggish in making decision perhaps because of the fear of failure and the risk attached to such decision making. Small scale entrepreneurs are always risk averter and this makes them to be very sluggish and slow in making decisions even those decisions that are very vital and important to the continuous existence and growth of the enterprise.

\section{Conclusion/Suggestion}

Small scale businesses in Africa takes about 85 percent of the indigenous businesses and large scale take the remaining share. But that notwithstanding, the large scale businesses, mostly multi-nationals, always overshadow the small scale businesses. But, according to Jaja, 2000, the small scale businesses have played an important role in our economy. Talk of employment generation, increase in production or rather total output of a nation, economic development via self-sufficiency, assisting the large scale businesses like in terms of distribution - linking producer with the final or end user, innovation of new products, carrying out repairs and other services.

We have also been made to realize that 'large scale businesses are the arms and legs of the economy, but small scale businesses are the brains' (Jaja, 2000). If this is agreed upon that a modern day computer cannot perform without the Central Processing Unit; the question comes to mind, why such neglect and lack of encouragement to the small scale entrepreneurs from governments, the large scale businesses and other relevant industries like the financial/banking houses?

However, the defense, still, will be that most of our small scale businesses go into business with blank mind. They do not always carry out research and feasibility study and where it is done; it is done with a lot of personal biasness. Some do not even know the importance of stating the objectives; not to talk of strategies and plans to use in achieving those objectives. The policy statement of the business is whatever the entrepreneur has in mind when a particular incident occurs. Finally, the teamwork in terms of management and control is virtually lacking. The entrepreneur, otherwise referred to as the owner-manager does the forecasting, planning, organizing, controlling and even evaluating and assessing of the enterprise, all alone. 
On this note, I will suggest that a more classical approach be made to being an entrepreneur of small scale business in Africa. Perhaps, emphasis will have to be placed on educational certificate and our universities to introduce at worst a diploma programme on Entrepreneurship running side-by-side with Business Administration, Marketing and so on. This is likely to reduce the problem of going into small scale business without feasibility study, definite and stated objectives and so on.

If you fail to plan, you are definitely planning to fail. But it is not too easy to plan all alone; which is why the principle of Total Quality Management (TQM) was postulated. Experts need to be given the chance of brainstorming with other managers not doing it all alone. This is why we have many entrepreneurs with stress related disease in Africa. As such, control and management of business must never be treated as a family or paternal issues. A good case study is that respected old man in Nigeria, that established a private university in the name of a religion and one of his wife is the sole contractor on ground, the wife was the only food vendor before the student went on rampage against that, one of his sons is the Registrar and he is the only think-tank of the establishment.

There is the need to be more accessible to modern day technology and information. Stanton William $J$ in "Fundamental of Marketing" said to manage information is to manage a business; and to do this, there is need to know what is going on around the globe called World through the Internet and Web sites.

Our State and Federal governments as well as other relevant authorities like chambers of commerce, banks and so on should stop politicizing issues relating to small scale businesses. Financial assistance in terms of reasonable soft and interest free loan, credit facilities, tax holidays and tax relief, workshops, with well implemented suggestions from such workshops and seminar. Our local government should be made to stop or reduce the levies and other burdens placed on our small scale businesses.

Finally, trade associations formed should be to protect its members rather than exposing its members. They should see to the well being of their members rather than fighting for power and also being allowed to be used by the government as a tool.

\section{References}

David, G., Marchwinski G., \& McSorley J. (1978). Case Study 32. MacDonalds Corporation.

Fubara, B. A. (1985). Business Management: Principles and Strategy. University Press Plc.

Jaja, S.A. (2000). The Entreprenuership Paradigm. Pearl Publishers.

Johninie, P.B., \& Nwasike, J.N. (2001). Organizational Behavior and Advanced Management Thought (An Epistemological Analysis). UNILAG Press.

Metcalf H.G., \& Urwick L.F. (1941). Dynamic Administration: The collected papers of Mary Parker Follet. Pitman.

Okwandu, G. A., \& Jaja, S. A. (2000). International Business Management. Pearl Publishers

Stanton, W. J. (1981). Fundamentals of Marketing (6th ed.). McGraw Hill.

Wood, F. (1978). Business Accounting I. ELBS. 